\title{
PENDIDIKAN KARAKTER DISIPLIN DI SEKOLAH DASAR
}

\author{
Wuri Wuryandani $^{1)}$, Bunyamin Maftuh, Sapriya, dan Dasim Budimansyah ${ }^{2)}$ \\ ${ }^{1)}$ Fakultas Ilmu Pendidikan Universitas Negeri Yogyakarta \\ ${ }^{2)}$ Sekolah Pascasarjana Universitas Pendidikan Indonesia \\ email: wurry_uny@yahoo.com.
}

\begin{abstract}
Abstrak: Penelitian ini bertujuan untuk menggali, mengkaji, dan mendiskripsikan pelaksanaan pendidikan karakter disiplin di sekolah dasar dan diharapkan dapat ditemukan kebijakan yang mendukung keberhasilan pendidikan karakter. Penelitian ini pendekatan kualitatif. Penelitian dilakukan di SD Muhammadiyah Sapen Yogyakarta, dengan subjek kepala sekolah, guru, dan siswa. Data dikumpulkan melalui observasi, wawancara, dan dokumentasi. Teknik pemeriksaan keabsahan data yang digunakan adalah teknik triangulasi. Hasil penelitian menunjukkan bahwa dalam melaksanakan pendidikan karakter disiplin di SD Muhammadiyah Sapen dilakukan melalui sembilan kebijakan, yaitu (1) membuat program pendidikan karakter; (2) menetapkan aturan sekolah dan aturan kelas; (3) melakukan sholat Dhuha dan Sholat Dhuhur berjamaah; (4) membuat pos afektif di setiap kelas; (5) memantau perilaku kedisiplinan siswa di rumah melalui buku catatan kegiatan harian; (6) memberikan pesan-pesan afektif di berbagai sudut sekolah; (7) melibatkan orang tua; (8) melibatkan komite sekolah; dan (9) menciptakan iklim kelas yang kondusif.
\end{abstract}

Kata Kunci: pendidikan karakter disiplin, sekolah dasar

\section{PENDIDIKAN KARAKTER DISIPLIN DI SEKOLAH DASAR}

\begin{abstract}
This study aims to explore, examine, and describe on implementation of discipline character education in elementary school and found a variety of policies that must be implemented to support the success of character education discipline. This study is a qualitative approach. This research was conducted in Muhammadiyah Sapen Yogyakarta Elementary School, with the subject principal, teachers, and student. Data were collected through observation, interviews, and documentation. Data validity used is the technique of triangulation. The results showed that in implementing character education of discipline in Muhammadiyah Sapen Yogyakarta Elementary School conducted through nine policies that (1) create a character education program; (2) define the rules of the school and classroom rules; 3) Duha and the Dhuhr prayer together; (4) make a post in the affective; (5) monitor the behavior of the students discipline in the home through daily activity logbook; (6) provide affective messages in various corners of the school; (7) involve parents; (8) involve the school committee; and (9) create a classroom climate that is conducive.
\end{abstract}

Keywords: character education discipline, elementary school

\section{PENDAHULUAN}

Penguatan pendidikan karakter di era sekarang merupakan hal yang penting untuk dilakukan mengingat banyaknya peristiwa yang menunjukkan terjadinya krisis moral baik di kalangan anak-anak, remaja, maupun orang tua. Oleh karena itu, penguatan pendidikan karakter perlu dilaksanakan sedini mungkin dimulai dari lingkungan keluarga, sekolah, dan meluas ke dalam lingkungan masyarakat.

Salah satu nilai karakter yang perlu dikembangkan adalah disiplin. Nilai karakter dis- iplin sangat penting dimiliki oleh manusia agar kemudian muncul nilai-nilai karakter yang baik lainnya. Pentingnya penguatan nilai karakter disiplin didasarkan pada alasan bahwa sekarang banyak terjadi perilaku menyimpang yang bertentangan dengan norma kedisiplinan. Perilaku tidak disiplin yang lain contohnya adalah membuang sampah sembarangan, parkir tidak di tempat yang telah ditentukan, tidak mematuhi perizinan mendirikan bangunan, dan sebagainya. Adanya perilaku melanggar tersebut menunjukkan belum adanya kesadaran masyarakat 
untuk berperilaku disiplin terhadap aturan yang telah ditetapkan pemerintah.

Perilaku tidak disiplin juga sering ditemui di lingkungan sekolah, termasuk sekolah dasar. Sebagai contoh perilaku tidak disiplin tersebut antara lain datang ke sekolah tidak tepat waktu, tidak memakai seragam yang lengkap sesuai dengan yang tercantum dalam tata tertib sekolah, duduk atau berjalan dengan seenaknya menginjak tanaman yang jelas-jelas sudah dipasang tulisan "dilarang menginjak tanaman", membuang sampah sembarangan, mencorat coret dinding sekolah, membolos sekolah, mengumpulkan tugas tidak tepat waktu, tidak menggunakan seragam sesuai aturan, dan lain-lain.

Terjadinya perilaku tidak disiplin di sekolah tersebut menunjukkan bahwa telah terjadi permasalahan serius dalam hal pendidikan karakter disiplin. Munculnya perilaku tidak disiplin menunjukkan bahwa pengetahuan yang terkait dengan karakter yang didapatkan siswa di sekolah tidak membawa dampak positif terhadap perubahan perilaku siswa sehari-hari. Pada dasarnya siswa tahu bahwa perilakunya tidak benar tetapi mereka tidak memiliki kemampuan untuk membiasakan diri menghindari perilaku yang salah tersebut. Hal ini merupakan dalam proses pendidikan karakter yang terjadi. Bisa jadi pendidikan karakter yang dilakukan selama ini baru pada tahap pengetahuan saja, belum sampai pada perasaan dan perilaku yang berkarakter.

Proses pembelajaran lebih banyak mengajarkan siswa pengetahuan verbalistik yang kurang mempersiapkan siswa agar mampu menghadapi kehidupan sosial yang akan mereka temui. Hal ini senada dengan yang dituliskan Suparno (2012:8) bahwa pendidikan kita masih terlalu menekankan segi kognitif. Ini pun masih terbatas pada mencari angka, bukan kemampuan analisis kritis siswa terhadap peristiwa yang dihadapi dalam kehidupan sehari-hari. Pendapat serupa disampaikan pula oleh Sugirin (2010:267) bahwa tolok ukur keberhasilan pendidikan selalu mengacu pada prestasi siswa yang terkait dengan ranah kognitif dan psikomotorik.
Suryadi (2012:96) menjelaskan bahwa penyebab utama terjadinya krisis moral dan karakter di kalangan peserta didik, lulusan, pendidik, bahkan pengelola pendidikan, adalah terjadinya dikotomisasi yaitu pemisahan secara tegas antara pendidikan intelektual di satu pihak dan pendidikan nilai di lain pihak. Padahal jika mendasarkan pada pendapat Bloom (1979: 7) ada tiga domain dalam pembelajaran yaitu kognitif, afektif, dan psikomotor. Ketiga domain tersebut harus dikembangkan secara komprehensif dalam pembelajaran. Demikian pula dalam hal pendidikan karakter, untuk dapat membentuk karakter yang baik dalam diri peserta didik, maka sekolah hendaknya mengembangkan tiga aspek penting, yaitu moral knowing (pengetahuan moral), moral feeling (perasaan moral), dan moral action (perilaku moral) (Lickona, 1991:53).

Sekolah sebagai lembaga pendidikan formal perlu memberikan perhatian khusus terhadap pendidikan karakter, sesuai dengan pendapat Johanson dkk. (2011:109) bahwa sekolah merupakan lembaga yang telah lama dipandang sebagai lembaga untuk mempersiapkan siswa untuk hidup, baik secara akademis dan sebagai agen moral dalam masyarakat. Lickona (1991: 45-46) menjelaskan bahwa sekolah merupakan salah satu lembaga pendidikan yang mengemban tugas mengembangkan nilai karakter. Nilai-nilai karakter itu antara lain kejujuran, keterbukaan, toleransi, kebijaksanaan, disiplin diri, kemanfaatan, saling menolong dan kasih sayang, keberanian, dan nilai-nilai demokrasi. Dari sejumlah nilai karakter yang perlu ditanamkan tersebut, disiplin diri merupakan salah satu nilai karakter yang penting dikembangkan.

Pendidikan di sekolah dasar merupakan jenjang pendidikan formal pertama yang akan menentukan arah pengembangan potensi peserta didik. Oleh karena itu, di sekolah dasar perlu mengembangkan karakter disiplin siswa secara optimal sehingga harapannya di tingkat selanjutnya siswa sudah memiliki bekal perilaku disiplin yang kuat. Mengingat demikian pentingnya pendidikan karakter disiplin di sekolah dasar, maka perlu dilakukan berbagai kebijakan 
sekolah yang dapat mendukung keberhasilan pendidikan karakter disiplin secara optimal.

\section{Pendidikan Karakter Disiplin}

Pendidikan karakter merupakan hal yang penting untuk ditanamkan kepada generasi muda. Orang tua, pendidik, institusi agama, organisasi kepemudaan memiliki tanggung jawab yang besar untuk membangun karakter, nilai, dan moral pada generasi muda (Krischenbaum, 1995:3). Pendidikan karakter bukanlah tanggung jawab segelintir orang atau lembaga tertentu saja. Pelaksanaan pendidikan karakter adalah tanggung jawab bersama, baik lingkungan keluarga, sekolah, dan masyarakat. Ketiga lingkungan pendidikan tersebut harus bekerja bersama-sama untuk mendukung konsistensi dan kontinuitas pendidikan karakter, sehingga dapat tercapai tujuan yang telah ditetapkan.

Untuk mendukung keberhasilan pendidikan karakter, perlu dilakukan sosialisasi tentang moral dasar yang perlu dimiliki anak dan remaja untuk mencegah remaja melakukan kejahatan yang dapat merugikan diri remaja itu sendiri maupun orang lain. Melalui pendidikan karakter akan tertanam nilai-nilai karakter yang baik di dalam diri individu. Nilai-nilai karakter yang baik akan menuntun seseorang dalam berperilaku sehari-hari. Pendapat tersebut senada dengan yang disampaikan Wibowo (2012: 36) bahwa pendidikan karakter merupakan proses pendidikan yang menanamkan dan mengembangkan karakter-karakter luhur kepada anak didik, sehingga mereka memiliki karakter luhur, dan menerapkan serta mempraktikan dalam kehidupannya, baik di lingkungan keluarga, warga masyarakat, maupun warga negara.

Pendidikan karakter tidak dapat dilakukan di dalam suatu ruang hampa (vacuum tube) yang bebas nilai karena karakter sangat erat (bounded) dengan kehidupan (Suryadi, 2012: 96). Berdasarkan penjelasan tersebut maka pendidikan karakter di sekolah tidak akan berhasil jika pembelajarannya hanya berupa hafalan secara verbalistik saja. Tidak ada jaminan jika pendidikan karakter itu berdiri sendiri sebagai mata pelajaran, maka akan berhasil dengan baik. Oleh karena itu, pelaksanaan pendidikan karakter di sekolah hendaknya dapat dilakukan dengan mengintegrasikan ke dalam mata pelajaran.

Ajat Sudrajat dan Ari Wibowo (2013) menjelaskan bahwa untuk membangun karakter peserta didik sekolah perlu menerapkan tiga program, yaitu (1) kultur sekolah bermutu yang mencakup mutu input, mutu akademik, dan mutu nonakademik; (2) kultur sekolah Islam dengan fokus penanaman karakter religius, keterbukaan, kepedulian, kebersamaan, dan kerja sama; (3) kultur disiplin dengan fokus penanaman karakter antara lain religius.

Pendidikan karakter disiplin merupakan hal penting untuk diperhatikan dalam rangka membina karakter seseorang. Berbekal nilai karakter disiplin akan mendorong tumbuhnya nilai-nilai karakter baik lainnya, seperti tanggung jawab, kejujuran, kerjasama, dan sebagainya Curvin \& Mindler (1999:12) mengemukakan bahwa ada tiga dimensi disiplin, yaitu (1) disiplin untuk mencegah masalah; (2) disiplin untuk memcahkan masalah agar tidak semakin buruk; dan (3) disiplin untuk mengatasi siswa yang berperilaku di luar kontrol.

\section{METODE}

Penelitian ini merupakan penelitian deskriptif dengan menggunakan pendekatan kualitatif. Penelitian ini bermaksud untuk membuat gambaran mengenai situasi atau kejadian, yaitu strategi implementasi nilai-nilai moral religius dalam proses pembelajaran di perguruan tinggi. Hal ini sejalan dengan pendapat Nazir (2005: 55) bahwa penelitian deskriptif bertujuan untuk membuat gambaran mengenai situasi atau kejadian sehingga berkehendak mengadakan akumulasi data dasar belaka. Penelitian ini dilakukan di SD Muhammadiyah Sapen Yogyakarta. Subjek penelitian ini adalah kepala sekolah, siswa, dan guru.

Teknik pengumpulan data yang digunakan dalam penelitian ini adalah wawancara, observasi, dan dokumentasi. Wawancara merupakan percakapan dengan maksud tertentu. Percakapan itu dilakukan oleh dua pihak, yaitu pewawancara (interviewer) yang mengajukan pertanyaan dan yang diwawancarai (intervie- 
wee) yang memberikan jawaban atas pertanyaan itu (Moleong, 2000:135). Wawancara digunakan untuk menjaring data atau informasi yang berkaitan dengan berbagai kebijakan yang dilakukan sekolah dalam pelaksanaan pendidikan karakter disiplin. Observasi dilakukan untuk melihat implementasi pendidikan karakter disiplin melalui pembelajaran di kelas. Dokumentasi digunakan untuk memperoleh data tentang tata tertib sekolah dan rencana pembelajaran yang dibuat oleh guru.

Untuk memperoleh data yang dapat dipertanggungjawabkan secara ilmiah, maka dalam penelitian ini dilakukan pemeriksaan keabsahan data. Dalam penelitian ini teknik pemeriksaan keabsahan data yang digunakan adalah teknik triangulasi, yaitu teknik penyilangan informasi yang diperoleh dari sumber sehingga pada akhirnya hanya data yang absah saja yang digunakan untuk mencapai hasil penelitian (Arikunto, 2006:18). Teknik triangulasi dilakukan dengan cara triangulasi metode, yaitu dengan mengecek ulang informasi hasil wawancara dengan dokumentasi dan observasi. Teknik analisis data yang digunakan dalam penelitian ini adalah teknik analisis induktif, yaitu analisis yang bertolak dari data dan bermuara pada simpulan-simpulan umum. Kesimpulan umum itu bisa berupa kategorisasi maupun proposisi (Bungin, 2001:209). Langkah-langkah analisis data tersebut meliputi: reduksi data, unitisasi dan kategorisasi, display data, dan penarikan kesimpulan.

\section{HASIL DAN PEMBAHASAN}

Dalam upaya mendukung keberhasilan pendidikan karakter disiplin di SD Muhammadiyah Sapen Yogyakarta dilakukan berbagai kebijakan oleh sekolah. Dalam pelaksanaan kebijakan tersebut sekolah menjalin kerjasama yang baik antara kepala sekolah, guru, karyawan, orang tua, dan komite sekolah. Berbagai kebijakan yang dilakukan SD Muhammadiyah Sapen tersebut adalah sebagai berikut.

\section{Program Pendidikan Karakter}

Program pendidikan karakter merupakan salah satu program sekolah yang dilaksanakan di SD Muhammadiyah Sapen Yogyakarta. Di dalam program pendidikan karakter ini salah satu yang dikembangkan adalah karakter disiplin. Penyusunan program pendidikan karakter dilakukan dengan melibatkan guru, orang tua, dan siswa. Hal ini mengingat bahwa untuk mendukung keberhasilan program pendidikan karakter perlu campur tangan baik dari pihak sekolah (guru), orang tua, dan masyarakat. Keterlibatan dari ketiga komponen tersebut dalam pendidikan karakter sesuai dengan pendapat Krischenbaum (1995:3) bahwa pendidikan karakter bukanlah tanggung jawab segelintir orang saja, tetapi perlu melibatkan komponen lain sseperti halnya orang tua, pendidik, institusi agama, organisasi kepemudaan. Masing-masing komponen yang mendukung keberhasilan pendidikan karakter tersebut harus saling bekerja sama. Demikian pula yang terjadi di SD Muhammadiyah Sapen Yogyakarta bahwa orang tua perlu ikut serta terlibat secara aktif dalam mendukung keberhasilan program pendidikan karakter yang dibuat oleh sekolah.

\section{Menetapkan Aturan Sekolah dan Aturan Kelas}

Berbicara masalah kedisiplinan, maka tidak dapat dilepaskan dengan pembicaraan tentang aturan. Di SD Muhammadiyah Sapen Yogyakarta aturan yang berlaku mencakup dua yaitu aturan sekolah dan aturan kelas. Keduanya memiliki peran yang cukup penting dalam mendisiplinkan seluruh komunitas sekolah ini. Aturan sekolah maupun aturan kelas berisi tentang berbagai hal terkait dengan tuntunan anggota komunitas di sekolah ini dalam berperilaku sehari-hari. Dengan adanya aturan sekolah maupun aturan kelas siswa akan memiliki pandangan yang jelas tentang apa saja yang harus dilakukan dan tidak boleh dilakukan, serta konsekuensi/sanksi terhadap pelanggaran aturan yang ada.

Aturan sekolah maupun aturan kelas berperan penting dalam mendisiplinkan siswa. Pentingnya aturan sekolah ini dikemukakan oleh Curvin \& Mendler (1999:8) bahwa terjadinya perilaku tidak disiplin pada siswa salah satu faktor penyebabnya adalah pembatasan 
yang tidak jelas. Dengan dituangkannya aturan sekolah maupun aturan kelas ke dalam tata tertib sekolah, maka batasan-batasan perilaku siswa di sekolah menjadi jelas.

Pentingnya pembuatan aturan sekolah maupun aturan kelas ini sesuai dengan pendapat Chiu \& Chow (2011:517) bahwa untuk menciptakan budaya disiplin di sekolah akan dipengaruhi salah satu faktor yaitu aturan sekolah dan norma-norma yang dapat mempengaruhi disiplin kelas. Dengan demikian, kebijakan SD Muhammadiyah Sapen Yogyakarta menetapkan aturan sekolah dan aturan kelas adalah tepat untuk menciptakan budaya disiplin baik di lingkungan sekolah, maupun lingkungan kelas khususnya.

Pendapat lain yang berkaitan dengan pentingnya aturan di sekolah adalah pendapat Nucci \& Narvaez (2008:122) yang menjelaskan bahwa norma berfungsi untuk mengatur praktek dan menilai perilaku manusia. Demikian pula halnya dengan aturan sekolah. Aturan ini dibuat dengan tujuan untuk memberikan tuntunan kepada warga sekolah tentang perbuatan apa saja yang seharusnya dilakukan dalam kehidupan sehari-hari di sekolah. Demikian pula Curvin \& Mindler (1999:20) menjelaskan bahwa aturan atau norma di kelas merupakan pusat untuk terlaksananya program kedisiplinan dan menjaga ketertiban.

Dalam membuat aturan kelas, siswa dilibatkan untuk mengembangkan penalaran moral siswa. Dalam pengembangan moralitas siswa perlu adanya tindakan dan komunikasi emosional antara siswa dan orang dewasa. Hal ini senada dengan pendapat Dahl, dkk., (2012:147) bahwa emosi dan komunikasi antara anak-anak dengan orang dewasa berpengaruh pada pembentukan sikap empati, dan belajar untuk memahami larangan. Oleh karena itu, agar anak lebih dapat memahami tentang mengapa perilaku tertentu dilarang atau tidak boleh dilakukan, ia perlu diajak berkomunikasi dengan melibatkan emosi yang sehat antara siswa dan guru.

Agar aturan sekolah maupun aturan kelas yang telah dibuat dapat dilaksanakan dengan baik, maka perlu dilakukan sosialisasi kepada orang tua siswa. Kegiatan ini dilakukan di awal tahun pelajaran oleh guru kelas. Kegiatan sosialisasi ini penting dilakukan agar orang tua dapat menjaga konsistensi pemberlakuan aturan di sekolah dengan di rumah sehingga terjadi kontinyuitas dalam penegakkan disiplin yang dilakukan di sekolah dan di rumah.

\section{Melakukan Sholat Dhuha dan Sholat Dhu- hur Berjamaah}

Salah satu kegiatan untuk menegakkan kedisiplinan di SD Muhammadiyah Sapen Yogyakarta adalah melalui kebijakan sholat berjamaah, yaitu untuk sholat dhuha dan sholat dhuhur. Melalui kegiatan sholat berjamaah ini siswa dilatih untuk tertib dalam melakukan ibadah, baik mulai persiapan, pelaksanaan hingga mengakhiri ibadah. Kegiatan sholat berjamaah ini diwarnai dengan pembiasaan-pembiasaan yang berkaitan dengan pengkondisian siwa untuk berdisiplin dalam beribadah.

\section{Membuat Pos Afektif di Setiap Kelas}

Pos afektif merupakan salah satu kebijakan yang dilakukan SD Muhammadiyah Sapen Yogyakarta guna menginternalisasikan nilai-nilai karakter kepada siswa, termasuk di dalamnya nilai karakter disiplin. Istilah pos afektif di sini digunakan untuk menyebut kegiatan di pagi hari yang berisikan pembiasaan dalam penyambutan siswa di pagi hari. Kegiatan ini diwarnai dengan berbagai hal terkait dengan penciptaan perilaku disiplin siswa. Kegiatan ini tidak hanya menjadi tanggung jawab guru kelas semata, tetapi lebih pada melibatkan siswa secara aktif dalam melakukan penyambutan kepada teman-temannya di pagi hari.

Kegiatan pos afektif akan difokuskan pada pembinaan kepada siswa dalam hal berperilaku tertib dalam memasuki kelas, melangkah, mengucap salam, berjabat tangan, meletakkan tas, dan sebagainya. Pada pagi hari guru kelas bersama siswa yang bertugas di hari itu sudah siap di depan kelas untuk melakukan penyambutan terhadap siswa yang datang di kelas.

Melalui kegiatan pos afektif ini siswa dilibatkan secara aktif dalam penegakan disiplin di SD Muhammadiyah Sapen Yogyakarta. Menurut Marlene Lockheed dan Andrian Vers- 
poor seperti dijelaskan oleh Suryadi (2012: 105-106) pelibatan siswa secara aktif dalam rangka untuk menciptakan kedisiplinan di sekolah merupakan tahap application stage, yaitu suatu tahap di mana siswa dilibatkan dalam kegiatan atau aplikasi atas pembiasaan dan pemahaman mengenai karakter dalam situasi yang nyata di sekolah. Melalui kegiatan yang melibatkan siswa secara aktif tersebut, maka diharapkan siswa akan memiliki konsep pembiasaan dan pemahaman terhadap karakter disiplin yang sedang digalakkan oleh sekolah dalam kegiatan yang senyatanya, tidak terbatas pada konsep-konsep disiplin secara abstrak.

\section{Memantau Perilaku Kedisiplinan Siswa di Rumah Melalui Buku Catatan Kegiatan Ha- rian}

Buku catatan kegiatan harian merupakan salah satu kebiajakan yang dilakukan di SD Muhammadiyah Sapen Yogyakarta untuk memantau perilaku disiplin siswa di rumah. Buku ini merupakan alat bagi guru untuk memantau kegiatan siswa di rumah dalam hal disiplin beribadah, belajar, dan kegiatan lain yang terkait dengan pengembangan disiplin siswa.

Adanya buku catatan kegiatan harian siswa bertujuan untuk menjaga konsistensi antara kegiatan siswa di sekolah dan di rumah. Konsistensi ini perlu dipantau dan dijaga untuk mendukung keberhasilan program pendidikan karakter disiplin yang sedang dikembangkan. Devine (2002:310) mengemukakan bahwa dalam rangka untuk mendisiplinkan siswa perlu dilakukan kontrol waktu dan ruang sebagai alat untuk memonitoring perilaku siswa. Melalui kontrol ruang dan waktu diharapkan secara bertahap akan muncul kesadaran diri siswa untuk berperilaku disiplin.

Kebijakan adanya buku catatan kegiatan harian ini sebagai upaya untuk melakukan monitoring terhadap perilaku siswa di rumah yang mana tidak mungkin untuk diamati guru secara satu per satu. Untuk menjaga efektivitas penggunaan buku catatan kegiatan harian ini tidak hanya siswa yang diberitahu tentang bagaimana pengisiannya, tetapi kepada orang tua juga diinformasikan tentang makna dan bagai- mana buku catatan kegiatan harian ini difungsikan agar dapat memberikan informasi yang tepat kepada sekolah tentang perilaku anak di rumah.

\section{Memberikan Pesan-pesan Afektif di Berba- gai Sudut Sekolah yang Mudah Dilihat oleh Warga Sekolah}

Pesan afektif tidak hanya diberikan secara lisan kepada siswa, tetapi juga diberikan melalui pesan-pesan yang ditempel di berbagai sudut sekolah yang mudah ditemui siswa setiap saat. Pesan-pesan afektif ini penting diberikan kepada siswa agar siswa senantiasa mengingat perilaku disiplin yang harus dilakukan, sehingga mereka akan melaksanakannya dalam perilaku sehari-hari di sekolah.

Pembuatan papan tempel untuk pesan afektif ini merupakan upaya sekolah untuk mensosialisasikan nilai-nilai karakter disiplin kepada peserta didik. Sosialisasi ini diperlukan agar seluruh siswa mengetahui nilai-nilai karakter yang dikembangkan sekolah. Berbekal pengetahuan tentang nilai-nilai karakter disiplin yang dikembangkan, secara bertahap siswa akan menginternalisasikan nilai-nilai karakter tersebut dalam dirinya dan pada akhirnya mereka akan berperilaku sesuai dengan nilai-nilai karakter yang terinternalisasi dalam dirinya tersebut.

Dalam proses internalisasi nilai karakter disiplin, sosialisasi tentang nilai-nilai karakter disiplin yang dikembangkan sekolah sangat penting dilakukan. Temuan tentang sosialisasi nilai karakter disiplin melalui pesan-pesan afektif yang ditempel di berbagai tempat di SD Muhammadiyah Sapen Yogyakarta ini didukung oleh pendapat Parsons (Ritzer \& Goodman, 2010:125) bahwa persyaratan kunci bagi terpeliharanya integrasi pola nilai di dalam sistem adalah melalui proses sosialisasi dan internalisasi. Melalui proses sosialisasi tentang nilai karakter disiplin yang dikembangkan diharapkan siswa akan memiliki pengetahuan tentang nilainilai karakter disiplin yang dikembangkan sekolah sehingga akan lebih mudah bagi mereka untuk menginternalisasi nilai-nilai tersebut dalam diri mereka masing-masing. Jika proses 
sosialisasi dan internalisasi nilai karakter disiplin ini berhasil, maka siswa akan memiliki kesadaran untuk berperilaku disiplin secara mandiri tanpa paksaan dari pihak manapun.

\section{Melibatkan Orang Tua dalam Pendidikan Karakter Disiplin}

Keterlibatan orang tua dalam mendukung keberhasilan pendidikan karakter disiplin yang dilakukan sekolah adalah hal penting yang tidak boleh diabaikan. Kegiatan ini dilakukan dengan tujuan agar orang tua dapat melakukan program pendidikan karakter disiplin yang dikembangkan di sekolah dalam kegiatan anak sehari-hari di rumah. di samping itu orang tua juga akan memberikan informasi tentang berbagai hal terkait dengan kegiatan atau perilaku anak di rumah. Jika perilaku tersebut positif, maka diberikan penguatan, sementara jika perilakunya menyimpang atau negatif, maka bersama-sama antara orang tua dan guru untuk mengatasinya.

Keterlibatan orang tua dalam pendidikan karakter disiplin ini sesuai dengan pendapat Sheldon \& Epstein (2002: 4) yang menjelaskan bahwa hubungan kerjasama yang erat antara sekolah, keluarga, dan masyarakat akan dapat meningkatkan perilaku disiplin siswa. Di samping itu, Chen \& Gregory (2011:447) juga menjelaskan bahwa keterlibatan orang tua dalam pendidikan siswa akan memiliki beberapa pengaruh positif yang ditunjukkan oleh indikator-indikator di antaranya perilaku siswa lebih lebih positif, nilai siswa menjadi lebih tinggi, kehadiran di sekolah lebih konsisten, dan lebih sedikit masalah disiplin.

Keterlibatan orang tua dalam pendidikan karakter disiplin dapat mencegah munculnya masalah perilaku siswa. Dengan demikian perilaku menyimpang atau perilaku tidak disiplin siswa dapat diminimalkan, ha ini senada dengan pendapat yang dikemukakan oleh Domina, (2005:233) bahwa keterlibatan orang tua keterlibatan orangtua tidak secara independen meningkatkan pembelajaran anak-anak, tetapi beberapa kegiatan keterlibatan yang dilakukan dapat mencegah masalah perilaku. Hal senada dikemukakan juga oleh Sheldon dan Epstein
(2002:4) bahwa keterlibatan antara orang tua dengan anak akan membantu untuk menurunkan kenakalan dan masalah perilaku siswa di sekolah.

Pentingnya keterlibatan orang tua dalam pendidikan karakter disiplin erat kaitannya dengan peran keluarga. Keluarga merupakan lingkungan terdekat dengan siswa dan sebagian besar waktu siswa habis di dalam lingkungan ini. Dengan demikian, keluarga memiliki peran yang besar dalam mengembangkan karakter disiplin anak dan memiliki porsi waktu yang banyak untuk mendisiplinkan anak. Hal ini senada dengan pendapat Lickona (2012:48) yang menjelaskan bahwa keluarga merupakan tempat yang paling dekat untuk anak mendapatkan pembelajaran. Lickona menjelaskan bahwa prestasi seorang anak akan dapat meningkat jika kedua orang tuanya di rumah, memperoleh perawatan yang baik, kemanan, ada rangsangan untuk perkembangan intelektualitasnya, adanya dorongan orang tua dalam hal pengaturan diri, adanya pembatasan terhadap anak dalam hal menonton televisi, dan orang tua memonitor anak dalam hal mengerjakan PR. Berdasarkan pendapat tersebut, Lickona juga menjelaskan bahwa keluarga merupakan fondasi pengembangan intelektual dan moral.

Peran keluarga dalam mendisiplinkan siswa salah satunya adalah dengan melakukan kontrol terhadap perilaku anak di rumah. Dalam hal ini orang tua dapat melakukan kontrol terhadap kedisiplinan anak dalam hal menonton $\mathrm{TV}$, main game, mengerjakan PR, belajar, beribadah, dan sebagainya. Jika ada perilaku anak yang menyimpang, maka orang tua perlu memberitahukan kepada pihak sekolah agar dapat dicari solusinya sehingga perilaku yang menyimpang dapat diatasi, dan anak kembali berperilaku sesuai dengan aturan yang ada.

\section{Melibatkan Komite Sekolah dalam Pendidi- kan Karakter Disiplin}

Unsur komite sekolah merupakan bagian dari masyarakat yang terlibat dalam pendidikan karakter disiplin. Masyarakat yang dalam hal ini diwakili oleh komite sekolah memiliki peran yang penting dalam mendukung keberhasil- 
an pendidikan karakter disiplin di sekolah. Alasan perlunya masyarakat terlibat dalam pendidikan karakter disiplin mengingat bahwa interaksi anak tidak hanya terbatas dengan guru dan teman sebaya serta orang tua saja, tetapi mereka juga berinteraksi dengan masyarakat lain yang lebih luas.

Pentingnya keterlibatan masyakarakat yang dalam hal ini diwakili oleh komite sekolah didasari dengan alasan bahwa masyarakat baik secara langsung maupun tidak langsung akan memberikan pengaruh yang positif terhadap pembentukan karakter peserta didik. Hal ini senada dengan pendapat Mulyasa (2011:75) bahwa terdapat pengaruh yang diberikan oleh lingkungan masyarakat yang positif terhadap pembentukan karakter peserta didik.

Komite sekolah dalam mendukung keberhasilan pendidikan karakter disiplin siswa dapat berperan sebagai mitra bagi sekolah dalam proses pengembangan karakter siswa. Kerjasama ini dapat diwujudkan dalam bentuk kerjasama dalam hal merumuskan program, mendukung pelaksanaan program secara materiil maun non materiil, memotivasi orang tua siswa untuk terlibat secara aktif, mengevaluasi pelaksanaan program dan sebagainya.

\section{Menciptakan Iklim Kelas yang Kondusif sebagai Laboratorium bagi Siswa untuk Berperilaku Disiplin}

Lingkungan yang kondusif penting untuk mendukung keberhasilan pelaksanaan pendidikan karakter disiplin di sekolah. Lingkungan yang kondusif ini dapat meliputi lingkungan fisik dan non fisik. Komponen-komponen lingkungan yang kondusif untuk mengembangkan disiplin di SD Muhammadiyah Sapen Yogyakarta meliputi komponen kepa sekolah, kebijakan sekolah, pengelolaan kelas, hubungan yang erat antara guru dan murid, serta pengelolaan kelas yang baik. Hal ini senada dengan pendapat Lickona (1991:325) bahwa ada 6 elemen yang harus dipenuhi oleh sebuah sekolah untuk dapat membudayakan moral di dalamnya, yaitu: (1) kepemimpinan dari kepala sekolah; (2) kebijakan untuk menegakkan disiplin; (3) membangun rasa kekeluargaan di sekolah; (4) pe- ngelolaan kelas yang demokratis; (5) menciptakan kerjasama yang erat antar orang dewasa; dan (6) menyisihkan waktu untuk menangani masalah-masalah moral yang timbul dalam lingkungan kehidupan sekolah baik yang kecil maupun besar.

Lingkungan kelas yang kondusif untuk pengembangan karakter disiplin siswa ini penting diperhatikan terutama untuk tingkat sekolah dasar karena anak-anak usia sekolah dasar akan lebih mudah dikembangkan karakternya melalui berbagai kegiatan/aktivitas kelas. Hal ini senada dengan pendapat Wynne (1991:139) bahwa untuk di sekolah dasar pengembangan karakter lebih banyak didasarkan aktivitas kelas.

Berry (1994:5) juga menjelaskan bahwa pada tingkat sekolah dasar kedisiplinan akan lebih mudah jika "tertangkap" oleh siswa, daripada hanya diajarkan secara verbal semata. Tertangkap di sini diartikan bahwa berbagai aktivitas kelas sehari-hari diwarnai dengan perilaku-perilaku disiplin baik itu dari guru, staf sekolah, maupun siswa itu sendiri. Siswa akan memperhatikan segala hal yang terjadi dikelas dan mereka akan mencontohnya dan mengaplikasikannya dalam perilaku sehari-hari. Di sinilah pentingnya role model bagi siswa.

Kebanyakan dari perilaku disiplin dalam aktivitas kelas sehari-hari tidak tertulis secara jelas dalam rencana pelaksanaan pembelajaran (RPP) yang dibuat oleh guru. Sebagian besar berbentuk kurikulum tersembunyi yang diwujudkan dalam perilaku guru sehari-hari. Kedisiplinan guru dalam memasuki ruang kelas, memakai pakaian seragam, mengelola kelas, kesemuanya diperhatikan oleh siswa. Hal ini senada dengan pendapat Hal ini senada dengan penjelasan Nucci \& Narvaez (2008:175) bahwa pendidik moral dan karakter memiliki peran utama dalam perkembangan moral siswa melalui kurikulum tersembunyi yang dimanifestasikan dalam lingkungan interpersonal sekolah dan ruang kelas.

Di dalam kelas guru perlu melakukan berbagai hal yang dapat mendukung keberhasilan program pendidikan karakter disiplin di antaranya menjalin hubungan erat dan hangat dengan siswa, menjadikan ruang kelas sebagai 
laboratorium disiplin bagi siswa, mengontrol perilaku sisa, dan menyediakan waktu untuk mengatasi masalah-maslah perilaku yang tidak sesuai dengan aturan yang seharusnya.

\section{PENUTUP}

Berdasarkan penelitian yang dilakukan di SD Muhammadiyah Sapen Yogyakarta ini dapat disimpulkan bahwa untuk mendukung tercapainya keberhasilan internalisasi nilai karakter disiplin di sekolah ini, dibuat sembilan kebijakan sekolah, yaitu program pendidikan karakter, menetapkan aturan sekolah dan aturan kelas, melakukan sholat Dhuha dan Sholat Dhuhur berjamaah, membuat pos afektif di setiap kelas, memantau perilaku kedisiplinan siswa di rumah melalui buku catatan kegiatan harian, memberikan pesan-pesan afektif di berbagai sudut sekolah, melibatkan orang tua, melibatkan komite sekolah, dan menciptakan iklim kelas yang kondusif.

Dalam pelaksanaan kesembilan kebijakan tersebut perlu dukungan dari seluruh warga sekolah baik kepala sekolah, guru, orang tua, komite sekolah, karyawan, dan siswa. Di samping itu, juga perlu perencanaan yang matang untuk menyusun program-program sekolah. Dalam pelaksanaannya juga perlu konsistensi yang kuat dari seluruh warga sekolah, terutama dalam hal pelaksanaan program dan penegakan aturan sekolah maupun aturan kelas.

\section{UCAPAN TERIMA KASIH}

Ucapan terima kasih peneliti sampaikan kepada Menteri Pendidikan dan Kebudayaan Republik Indonesia yang telah memberikan bantuan beasiswa BPPS untuk menyelesaikan penelitian dan studi program doktor. Artikel ini merupakan bagian dari penelitian disertasi untuk menyelesaikan program doktor Pendidikan Kewarganegaraan di Sekolah Pascasarjana Universitas Pendidikan Indonesia.

\section{DAFTAR PUSTAKA}

Arikunto, S. 2006. Prosedur Penelitian Suatu Pendekatan dan Praktek. Jakarta: Rineka Cipta.
Berry, R. S., 1994. 100 Ideas That Work Discipline In The Classroom. Philipines: ACSI Publications.

Bloom, B.S., 1979. Taxonomy Of Educational Objectives Book 1: Cognitive Domain. London: Longman Group LTD.

Bungin, B. 2001. Metodologi Penelitian Kualitatif: Aktualisasi Metodologis ke Arah Ragam Varian Kontemporer. Jakarta: Raja Grafindo Persada.

Chen, W.B., \& Gregory. 2011. "Parental Involvement In The Prereferral Process: Iimplications For Schools". Remedial and Special Education, 32 (6), hlm. 447457.

Chiu, M.M., \& Chow, B.W.Y. 2011. "Classroom Discipline Across Forty-One Countries: School, Economic, And Cultural Differences". Journal Of Cross-Cultural Psychology, 42 (3), Hlm. 516- 533.

Curvin, R. L., \& Mindler, A. N. 1999. Discipline With Dignity. USA: Association For Supervision And Curriculum Development.

Dahl, A, Campos, J. J., \& Witherington, D. C. 2011. "Emotional Action And Communication In Early Moral Development". Emotion Revie, 3 (2), hlm.147-157.

Devine, D. 2002. "Children's Citizenship and the Structuring of Adult Child Relations in the Primary School". Childhood, 9 (3), Hlm. 303-320.

Domina, T. 2005. "Levelling the Home advantage: Assessing the Effectiveness of Parental Involvement in Elementary School". Sociology of Education, 78, hlm. 233-249.

Johansson, E., dkk. 2011. "Practices For Teaching Moral Values in the Early Years: A 
Call for a Pedagogy Of Participation". Education, Citizenship And Social Justice, 6 (2), Hlm. 109-124.

Kirschenbaum, H. 1995. 100 Ways To Enhance Values And Morality In Schools And Youth Setting. London: Allyn And Bacon.

Lickona, T. 1991. Educating For Character. New York: Bantam Books.

Lickona, T. 2012. Character matters: persoalan karakter, bagaimana membantu anak mengembangkan penilaian yang baik, integritas, dan kebajikan penting lainnya (Terjemahan). Jakarta: Bumi Aksara.

Moleong, L. J. 2007. Metode Penelitian Kualitatif. Bandung: Remaja Rosda Karya.

Mulyasa, E. 2011. Manajemen Pendidikan Karakter. Jakarta: Bumi Aksara.

Nazir, M. 2005. Metode Penelitian. Bogor: Ghalia Indonesia.

Nucci, L. P., \& Narvaez, D. 2008. Handbook Of Moral And Character Education. New York: Routledge.

Ritzer, G. \& Goodman, D. J. 2010. Teori Sosiologi Modern. Jakarta: Kencana Perdana Media Group.

Sheldon, S. B \& Epstein, J. L. 2002. "Improving Student Behavior And School Discipline with Family and Community Involvement". Education And Urban Society, 35 (1), Hlm. 4-26.
Sudrajat, A. \& Wibowo, A. 2013. "Pembentukan Karakter Terpuji di Sekolah Dasar Muhammadiyah Condongcatur". Jurnal Pendidikan Karakter, 1 (2), Hlm. 174185

Sugirin. 2010. "Affective Domain Development: Reality And Expectation". Cakrawala Pendidikan, 3 (XXIX), Hlm. 267279.

Suparno, P. 2012. Harapan Untuk Kurikulum Baru. Kompas, 29 September 2012.

Suryadi, A. 2012. Outlook 2025 Pembangunan Pendidikan Indonesia: Menuju Kualitas Yang Berdaya Saing Secara Global (The Indonesian Education Outlook 2025: Toward A Sustainable World Class Quality Level). Jakarta: Badan Penelitian Dan Pengembangan Kementerian Pendidikan Dan Kebudayaan.

Wibowo, A. 2012. Pendidikan Karakter: Strategi Membangun Karakter Bangsa Berperadaban. Yogyakarta: Pustaka Pelajar.

Wynne, E. A. 1991. "Character And Academics In The Elementary School". Dalam Benninga J.S. (Penyunting). Moral, Character, And Civic Education In The Elementary School. New York: Teachers College, Columbia University. 